\title{
Milk and açaí berry pulp improve sensorial acceptability of kefir-fermented milk beverage
}

\author{
Lara Kozlowski NOGUEIRA, Elizama AGUIAR-OLIVEIRA², Eliana Setsuko KAMIMURA³, \\ Rafael Resende MALDONADO ${ }^{1,4^{*}}$ \\ ${ }^{1}$ Faculdade Municipal Professor Franco Montoro (FMPFM), Rua dos Estudantes s.n., Postal Code: 13.843-971, Mogi Guaçu, SP, Brazil. \\ 2 Universidade Federal da Bahia (UFBA), campus Anísio Teixeira (CAT), Instituto Multidisciplinar em Saúde(IMS), Departamento de Biociências, R. Rio de Contas, 58, Candeias, \\ Postal Code: 45.029-094, Vitória da Conquista, Bahia, Brazil. \\ ${ }^{3}$ Universidade de São Paulo (USP), Faculdade de Zootecnia e Engenharia de Alimentos (FZEA), Av. Duque de Caxias, 225, Postal Code: 13.635-900, Pirassununga, \\ São Paulo, Brazil. \\ ${ }^{4}$ Universidade Estadual de Campinas (UNICAMP), Colégio Técnico de Campinas (COTUCA), Departamento de Alimentos, R. Jorge Figueiredo Corrêa, 735, Parque Taquaral, \\ Postal Code: 13087-261, Campinas, São Paulo, Brazil. \\ * Corresponding author: ratafta@yahoo.com.br
}

\section{ABSTRACT}

Kefir grains are a symbiotic biomass (yeast and bacteria) commonly used to produce milk probiotic fermented beverages. The aim of this study was to produce a mixed beverage of whole milk and açai (Euterpe oleracea) berry pulp fermented by two different kefir cultures: one specific for milk and one specific for sugared water, adapted to milk. Based on the fermentation

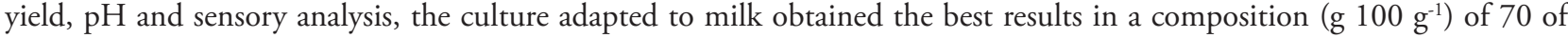
whole milk and 30 of açai berry pulp, at room temperature $\left(-25^{\circ} \mathrm{C}\right)$, without agitation and fermented for $24 \mathrm{~h}$. The results obtained by this formulation were an increase of $12 \%$ in the kefir biomass, $93 \%$ of fermentation yield, $\mathrm{pH} 5.10$ and overall sensory acceptance of 7.05 .

KEYWORDS: Euterpe oleracea, kefir, milk, fermentation, sensorial acceptance.

\section{Leite e polpa de açaí aumentam a aceitabilidade sensorial de uma bebida fermentada por kefir}

\begin{abstract}
RESUMO
Kefir é uma biomassa simbiótica (leveduras e bactérias) comumente aplicada na obtenção de bebidas fermentadas probióticas de leite. O objetivo deste trabalho foi produzir uma bebida fermentada mista de leite integral e polpa de açaí (Euterpe oleracea) a partir de duas culturas diferentes de kefir: uma original de leite e outra original de água açucarada e adaptada ao leite. Com base na conversão, $\mathrm{pH}$ e análise sensorial, os melhores resultados foram obtidos com a cultura adaptada na composição (g $100 \mathrm{~g}^{-1}$ ) de $70 \%$ de leite e $30 \%$ de polpa de açaí, sem controle de temperatura (temperatura ambiente $-25^{\circ} \mathrm{C}$ ) e sem agitação e por $24 \mathrm{~h}$ de fermentação. Esta formulação apresentou 12\% de aumento da biomassa, 93\% de conversão, pH 5,10 e uma aceitação global de 7,05.
\end{abstract}

PALAVRAS-CHAVE: Euterpe oleracea, kefir, leite, fermentação, aceitação global. 


\section{INTRODUCTION}

Kefir is one of a very few fermented beverages obtained by the simultaneous lactic and alcoholic fermentation of milk, water with sugar or fruit pulp, utilizing a kefir culture. The resulting beverage is slightly carbonated, with a variable quantity of alcohol and also present prebiotic and probiotic effects. The kefir culture is compound by a symbiotic biomass formed by different species of bacteria and yeast, which is wrapped in a matrix known as kefiran, a polysaccharide gel. The kefir grains have an irregular shape, vary in length between 0.5 and $3.5 \mathrm{~cm}$ and its color might vary depending on the sort of microorganisms and the place of origin of the culture (Leite et al. 2013; Lopitz-Otsoa et al. 2006; Stepaniak and Fetliński 2002).

The beverage resultant from the double fermentation (lactic and alcoholic) presents a variety of acids such as lactic, acetic, gluconic, formic, succinic, and propionic. The formation of carbonic gas; vitamin B12 and polysaccharides (Weschenfelder et al. 2011); different aldehydes, isoamyl alcohol and traces of acetone (Moreira et al. 2008) also occurs. When the kefir grains are inoculated in the culture medium, an adaptation (lag) phase occurs at first. After that, the fermentation (sugar consumption) begins. Due to the alcoholic fermentation, there is release of a large amount of $\mathrm{CO}_{2}$ and increase in temperature occurs. This process is known as the turbulent phase. When the sugar consumption is nearly finished, the production of $\mathrm{CO}_{2}$ and the temperature eventually lower. With regard to the lactic acid fermentation, there is a partial anaerobic conversion of carbohydrates, mainly glucose, into lactic acid.

The fermentation of kefir is usually conducted in milk or whey (Balabanova and Panayotov 2011; Hsieh et al. 2012; Soupioni et al. 2013). However, it can also be performed in different substrates, which can diversify the flavor and enhance the acceptance of the product by consumers. As examples, the usage of walnut milk (Cui et al. 2013), cocoa pulp (Puerari et al. 2012), sugar cane juice (Dornelles and Rodrigues 2006), orange pulp (Plessas et al. 2008) and also water and brown sugar solutions (Bergmann et al. 2010; Diniz et al. 2003; Moreira et al. 2008) can be cited.

Brazil is the largest producer and exporter of the açai berry, a fruit of Euterpe oleracea, which is native to the Amazon (Menezes et al. 2008; Miao and Wu, 2014). The açai berry is consumed as juice or smoothie in Brazil; the pulp is a rich source of calories, vitamin E, dietary fiber, manganese, copper, boron, calcium, magnesium, potassium, and chromium. It also contains a small quantity of total sugar, phosphorus, sodium, zinc and iron (Oliveira et al. 2011). Therefore, the aim of this study was to develop a mixed beverage of whole milk and açai berry pulp fermented by kefir utilizing two different cultures.

\section{MATERIALS AND METHODS}

\section{Fermentations}

The kefir cultures were obtained from small farmers from the states of São Paulo and Paraná (Brazil). Two cultures of kefir were evaluated: one originally cultivated in milk and one originally cultivated in a solution of brown sugar, adapted to milk. The adaptation from the sugar solution to milk was performed, at first, by the transference of the kefir culture to plain mineral water. It was left incubating for 24 hours at room temperature $\left(-25^{\circ} \mathrm{C}\right)$, without agitation, in order to completely remove the sugar. After this period, the culture was transferred to flasks containing whole milk and left incubating under similar conditions

The preliminary tests were conducted to evaluate the growth of the kefir grains and its behavior during the fermentation process in the mixed substrate (whole milk and açai berry pulp).The frozen pulp of açai berry and the whole milk (UHT - ultra high temperature process) were bought in local supermarkets in the city of Mogi Guaçu-SP (Brazil). Six different samples of whole milk and açaí berry pulp were fermented by both kefir cultures and evaluated. The proportions utilized were: $\left(\mathrm{g} \mathrm{g}^{-1}\right): 1=100 / 0 ; 2=90 / 10 ; 3=$ $70 / 30 ; 4=50 / 50 ; 5=30 / 70$, and $6=10 / 90$. The formulations were blitzed for 1 minute in order to become homogeneous. Subsequently, the kefir cultures were inoculated into the formulations at the concentration of $5.0 \mathrm{~g} 100 \mathrm{~g} \mathrm{~g}^{-1}$ in flasks containing $100 \mathrm{~g}$ of each sample. The fermentation flasks were previously cleansed with detergent and rinsed with boiling water. After the inoculation, there were covered with paper tissues and incubated at room temperature $\left(-25^{\circ} \mathrm{C}\right)$ without agitation for 24 hours (Weschenfelder et al. 2011). Subsequent to the fermentation, the kefir cultures were separated from the beverages with the aid of a kitchen sieve. The beverages and kefir biomass were utilized to measure the fermentation variables: mass, $\mathrm{pH}$, concentration of soluble solids of the substrate and the fermented beverage, and also the initial and final mass of the kefir grains. All fermentation conditions were performed in triplicate and the results were analyzed by means of the average values, standard deviation and coefficient of variation. Average values were compared utilizing the Tukey test.

After the preliminary tests, two formulations were selected with the whole milk/açai berry pulp proportions $\left(\mathrm{g} \mathrm{g}^{-1}\right)$ : $70 / 30$ and 30/70. Both kefir cultures, original and adapted, and the same conditions of inoculation and incubation from the preliminary tests, were applied. For each formulation, 10 replicates were performed and the average values of each parameter were compared by Tukey test. The parameters measured were $\mathrm{pH}$, concentration of soluble solids of the 
substrate and of the fermented beverage, initial and final mass of the kefir biomass and sensory acceptance.

\section{Sensorial acceptance}

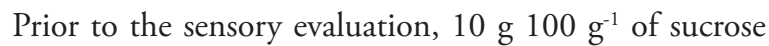
were added to the beverages in order to promote the balance of the sweet/acid ratio. The sensory evaluation was performed by means of an acceptance test with 50 untrained panelists recruited randomly (both genders, between 20 and 30 years of age) at the Municipal College Professor Franco Montoro (Mogi Guaçu-SP, Brazil). The test employed a verbal hedonic scale of 9 points $(9=$ liked very much, 1 disliked very much) (Stone and Sidel 1993). The attributes evaluated were color, aroma, taste, sweetness, acidity and overall acceptance in order to determine the sensory acceptance of the fermented beverages evaluated. The results were utilized to calculate the average mean and standard deviation for each attribute and the comparison of the average mean of the attributes was performed with ANOVA and Tukey test. The sensory analysis followed the ethical standards for researches involving humans and the project was previously approved by the Ethics Committee of the Institution and it was registered in the Brazil Platform of the Brazilian Ministry of Health (CAAE: 29863314.7.0000.5425) as determines the Brazilian legislation on ethics in research.

\section{Analytical methods}

The mass of substrate, fermented beverage and kefir grains were determined in semi-analytical scale (Adventurer ${ }^{\mathrm{TM}}$ AR5120, Ohaus, Parsippany, USA), the hydrogen concentration $(\mathrm{pH})$ was measured in a $\mathrm{pH}$-meter (W3B, Bel Engineering, Monza, Italy) and the concentration of soluble solids (SS) was determined with a portable refractometer (ITREF 25, Instrutemp, São Paulo, SP). The yield of fermented beverage $(R)$ and the variation of mass of the kefir grains $(\Delta \mathrm{m})$ were calculated according to equations 1 and 2 , respectively. In these equations, $\mathrm{m}_{\mathrm{S}}$ and $\mathrm{m}_{\mathrm{F}}$ denote the mass of substrate and mass of fermented beverage, and $\mathrm{m}_{\mathrm{kt}}$ and $\mathrm{m}_{\mathrm{ko}}$ represent the mass of kefir biomass at the beginning and at the end of fermentation, respectively.

$$
\begin{array}{ll}
R(\%)=100 *\left[\left(m_{S}-m_{F}\right) / m_{F}\right] & (\text { Equation 1) } \\
\Delta m(\%)=100 *\left[\left(m_{k t}-m_{k o}\right) / m_{k o}\right] & (\text { Equation 2) }
\end{array}
$$

\section{RESULTS}

\section{Preliminary tests}

Beverage fermented with the original kefir culture. Considering a confidence level of $94 \%$, the variance analysis (ANOVA) (Table 1) shows that there was no statistically significant difference $(p<0.06)$ among the formulations for both results evaluated, $\Delta \mathrm{m}$ (Figure $1 \mathrm{~A}$ ) and $\mathrm{R}$ (Figure $1 \mathrm{~B})$, and based on that, the formulations which presented the smallest variations among the triplicates were chosen for further analyses: formulations $5\left(70 / 30 \mathrm{~g} \mathrm{~g}^{-1}\right.$ of milk/açai $)$ and $3\left(30 / 70 \mathrm{~g} \mathrm{~g}^{-1}\right.$ of milk/açai), with the respective variabilities of $\Delta \mathrm{m}=(8.3 \pm 0.9) \%$ and $\mathrm{R}=(90.7 \pm 1.0) \%$.

As a result of the amount of açai berry in formulations, higher concentrations led to a decrease in soluble solids concentration (SS, Fig. 1c) and $\mathrm{pH}$ (Figure 1D) at the beginning and at the end of fermentations.

Fermented beverage with adapted kefir culture. According to the results, the replicates of the adapted kefir culture were more reproducible than those from the original kefir culture (Figures 2A,B).The $p$-value of the replicates was higher $(0.18)$, which indicates that the replicates can be considered equals; nonetheless, the $p$-value of the formulations was lower (0.02), which indicates a significant difference among the formulations evaluated (Table 1). The honest significant differences (HSD) among the formulations were obtained at $95 \%$ of confidence as: $9.25 \%$ for $\Delta \mathrm{m}$ and $3.08 \%$ for R. Formulation $5\left(30 / 70 \mathrm{~g} \mathrm{~g}^{-1}\right.$ milk/açai) presented a $\Delta \mathrm{m}$ value not statistically different from formulation 3 (70/30 g $\mathrm{g}^{-1}$ milk/açai) with $95 \%$ of confidence (Table 2); these two

Table 1. Summary of the Analysis of Variance (ANOVA) for the variation of mass of the kefir grains $(\Delta m)$ and yield of fermented beverage $(R)$ for the mixed fermented beverage of whole milk and açaí berry pulp using the original and the adapted kefir cultures at the preliminary tests.

\begin{tabular}{lcccc}
\hline & \multicolumn{2}{c}{ Original kefir } & \multicolumn{2}{c}{ Adapted kefir } \\
\hline & \multicolumn{4}{c}{$\Delta \mathrm{m}(\%)$} \\
\hline Source of Variation & $\boldsymbol{F}$-test & $\boldsymbol{p}$-value & $\boldsymbol{F}$-test & $\boldsymbol{p}$-value \\
\hline Replicates & 3.70 & 0.06 & 2.06 & 0.18 \\
Formulations & 0.20 & 0.96 & 4.52 & 0.02 \\
\hline \multicolumn{5}{c}{$\mathrm{R}(\%)$} \\
\hline Source of Variation & $\boldsymbol{F}$-test & $\boldsymbol{p}$-value & $\boldsymbol{F}$-test & $\boldsymbol{p}$-value \\
\hline Replicates & 3.85 & 0.06 & 3.40 & 0.072 \\
Formulations & 0.74 & 0.61 & 10.46 & 0.001 \\
\hline
\end{tabular}

Table 2. Average values for the variation of the mass of the kefir grains $(\Delta \mathrm{m})$ and yield of fermented beverage $(R)$ of mixed fermented beverages of whole milk and açaí berry pulp using the adapted kefir culture. Formulations evaluated were composed of ( $\mathrm{g} \mathrm{g}^{-1}$ of whole milk/açaí berry pulp): $1=100 / 0,2=90 / 10$, $3=70 / 30,4=50 / 50,5=30 / 70 ; 6=10 / 90$.

\begin{tabular}{lcl}
\hline Formulation & $\Delta \mathrm{m}(\%)$ & $\mathrm{R}(\%)$ \\
\hline 1 & $3.2^{\mathrm{a}}$ & $95.3^{\mathrm{a}}$ \\
2 & $6.2^{\mathrm{a}}$ & $90.0^{\mathrm{b}}$ \\
3 & $11.2^{\mathrm{a}, \mathrm{b}}$ & $89.9^{\mathrm{b}}$ \\
4 & $10.5^{\mathrm{a}}$ & $89.2^{\mathrm{b}}$ \\
5 & $20.0^{\mathrm{b}}$ & $87.4^{\mathrm{b}}$ \\
6 & $10.4^{\mathrm{a}}$ & $87.6^{\mathrm{b}}$ \\
\hline
\end{tabular}

*Conditions marked with different letters present statistically significant difference with $95 \%$ of confidence $(p<0.05)$. 

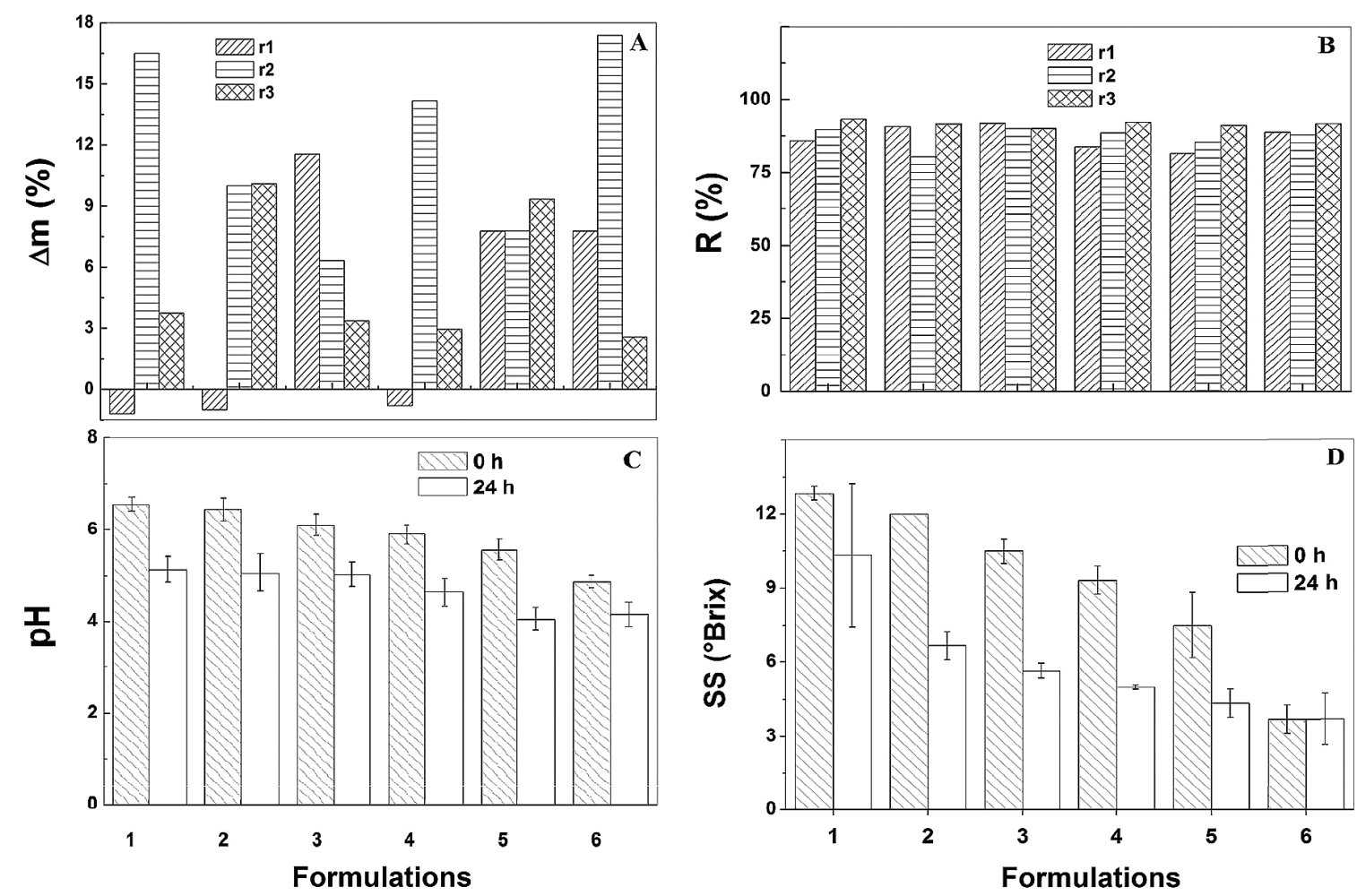

Figure 1. Data from preliminary tests for the production of mixed fermented beverage of whole milk and açaí berry using the original kefir culture from milk. A: Variation of the mass of the kefir grains $(\Delta \mathrm{m}, \%), \mathrm{B}$ : yield of fermented beverage $(\mathrm{R}, \%), \mathrm{C}$ : $\mathrm{pH}$ and $\mathrm{D}$ : soluble solids concentration (SS, $\left.{ }^{\circ} \mathrm{Brix}\right)$. The $\Delta \mathrm{m}$ and $\mathrm{R}$ values are presented for each triplicate $(\mathrm{r} 1, \mathrm{r} 2, \mathrm{r} 3)$ and the $\mathrm{pH}$ and SS values are presented as average and standard deviations (bars) at 0 and $24 \mathrm{~h}$. Six formulations were evaluated ( $\mathrm{g} \mathrm{g}^{-1}$ of milk/açal): $1=100 / 0,2=90 / 10,3=70 / 30,4=50 / 50,5=30 / 70,6=10 / 90$. Fermentations were carried out at room

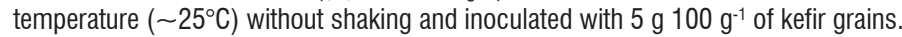

formulations (the same as for the original kefir culture) were selected for further evaluations.

\section{Fermentation utilizing original and adapted kefir cultures}

The selected formulations $\left[3: 70 / 30 \mathrm{~g} \mathrm{~g}^{-1}\right.$ milk/açai and 5: $30 / 70 \mathrm{~g} \mathrm{~g}^{-1}$ milk/açai] from the two kefir cultures [original and adapted] were prepared once more but with ten replicates for each condition. The average values obtained for the mass variation of the kefir culture $(\Delta \mathrm{m})$, the fermented beverage yield (R), the $\mathrm{pH}$ and the soluble solids concentration (SS) are presented on Table 3. Considering the same culture, no significant difference was observed for $\Delta \mathrm{m}$ (Table 3) with both formulations ( 3 and 5 ), nevertheless, when comparing different cultures, there was a significant difference $(p<0.05)$. A significant difference $(p<0.05)$ among the formulations was also identified for $\mathrm{R}$.

The initial $\mathrm{pH}$ value was influenced by the composition of the formulations. The increase in the quantity of açai berry pulp in the formulations resulted in the diminution of the initial $\mathrm{pH}$ value; at the end of fermentations it was observed a decrease in the $\mathrm{pH}$ values. The formulation with the highest content of açai berry pulp obtained the lowest $\mathrm{pH}$ values, nevertheless, the diminution of $\mathrm{pH}$ was less accentuated when the adapted kefir culture was utilized.

\section{Sensorial Analysis}

The results obtained for the sensorial analysis are shown in Table 4, from which it can be observed that all formulations showed average attribute values within the acceptable range (above5.0). In general, a product is considered accepted when the overall average value is higher or equal to 7.0 (Stone and Sidel 1993); by this standard, only the formulation containing $70 / 30 \mathrm{~g} \mathrm{~g}^{-1}$ (milk/açai) using the adapted kefir culture can be considered acceptable (overall average of 7.05). However, considering that this is a new product and that none of the average results is below 5, it can be considered that the results obtained were satisfactory.

According to the ANOVA (data not shown), most of the evaluated attributes (color, taste, sweetness and acidity) did not presented any statistically significant difference $(p<0.05)$; for flavor and overall acceptance there was a statistically 

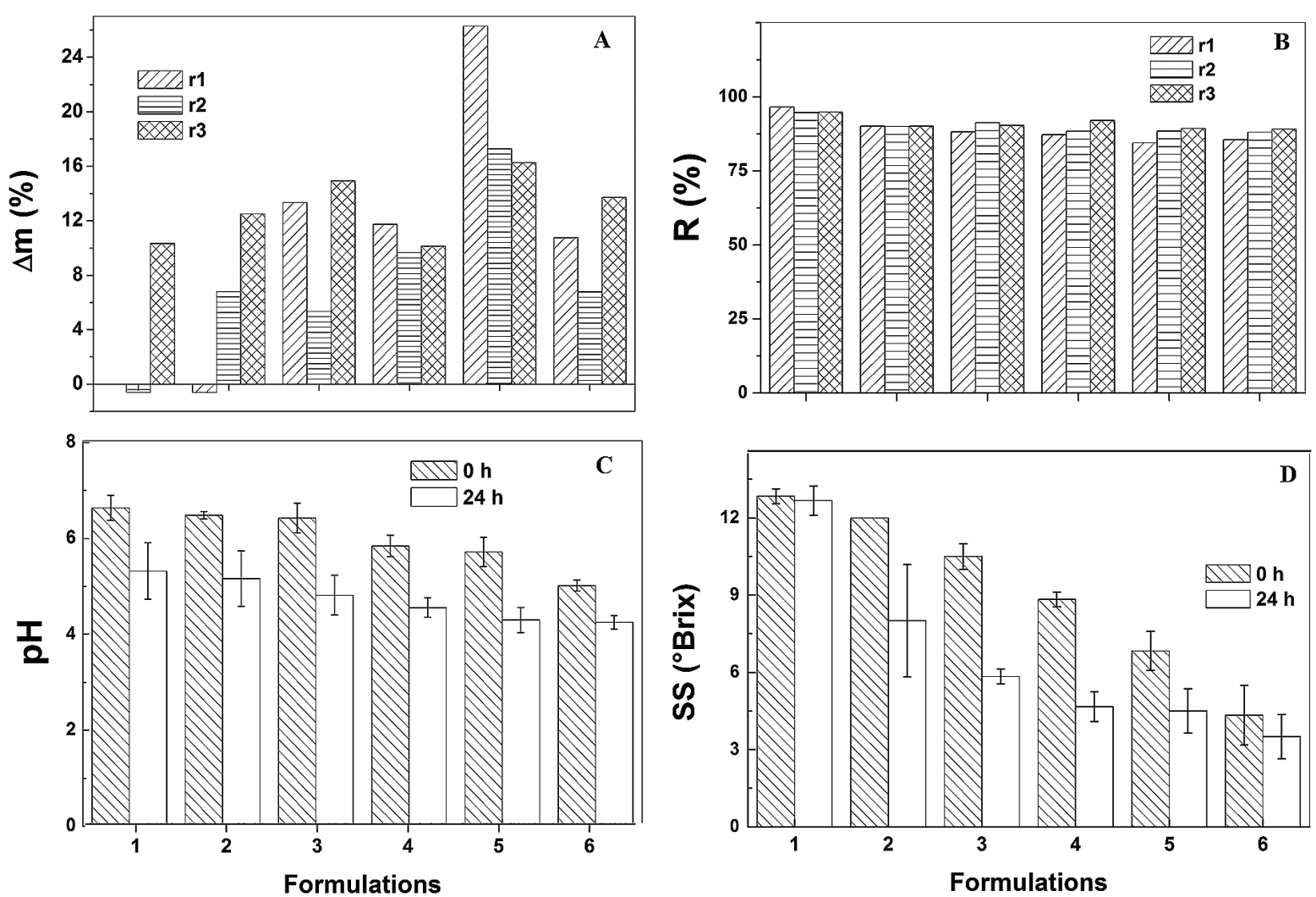

Figure 2. Data from preliminary tests for the production of mixed fermented beverage of whole milk and açaí berry using the adapted kefir culture from milk. $\mathrm{A}$ : Variation of the mass of the kefir grains $(\Delta \mathrm{m}, \%), \mathrm{B}$ : yield of fermented beverage $(\mathrm{R}, \%), \mathrm{C}$ : $\mathrm{pH}$ and $\mathrm{D}$ : soluble solids concentration (SS, $\left.{ }^{\circ} \mathrm{Brix}\right)$. The $\Delta \mathrm{m}$ and $\mathrm{R}$ values are presented for each triplicate $(\mathrm{r} 1, \mathrm{r} 2, \mathrm{r} 3$ ) and the $\mathrm{pH}$ and SS values are presented as average and standard deviations (bars) at 0 and $24 \mathrm{~h}$. 6 formulations were evaluated ( $\mathrm{g} \mathrm{g}^{-1}$ of milk/açal): $1=100 / 0,2=90 / 10,3=70 / 30,4=50 / 50,5=30 / 70,6=10 / 90$. Fermentations were carried out at room

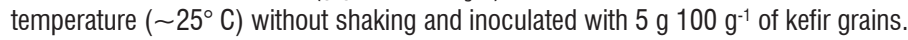

Table 3. Average values ( $n=10$ replicates) for the variation of the mass of the kefir grains $(\Delta m, \%)$, yield of fermented beverage $(R, \%), p H$ and concentration of soluble solids (SS, ${ }^{\circ}$ Brix) for the mixed fermented beverage of whole milk and açaí berry pulp. Fermentations were conducted with 2 kefir cultures - original and adapted, and 2 formulations of whole milk and açaí berry pulp of: $70 / 30$ and $30 / 70\left(\mathrm{~g} \mathrm{~g}^{-1}\right)$ without shaking and at room temperature $\left(\sim 25^{\circ} \mathrm{C}\right)$ for $24 \mathrm{~h}$.

\begin{tabular}{lcccc}
\hline & \multicolumn{2}{c}{ Original kefir culture } & \multicolumn{2}{c}{ Adapted kefir culture } \\
\hline & $70 / 30$ & $30 / 70$ & $70 / 30$ & $30 / 70$ \\
$\Delta \mathrm{m}(\%)$ & $27.70 \pm 4.61^{\mathrm{a}}$ & $29.00 \pm 3.90^{\mathrm{a}}$ & $12.25 \pm 4.27^{\mathrm{b}}$ & $14.22 \pm 3.99^{\mathrm{b}}$ \\
$\mathrm{R}(\%)$ & $91.40 \pm 1.47^{\mathrm{a}}$ & $91.40 \pm 1.09^{\mathrm{a}}$ & $93.46 \pm 0.93^{\mathrm{b}}$ & $92.99 \pm 0.98^{\mathrm{a}, \mathrm{b}}$ \\
$\mathrm{pH}_{0 \mathrm{~h}}$ & $5.94 \pm 0.00^{\mathrm{a}}$ & $5.33 \pm 0.00^{\mathrm{b}}$ & $5.94 \pm 0.00^{\mathrm{a}}$ & $5.33 \pm 0.00^{\mathrm{b}}$ \\
$\mathrm{pH}_{24 \mathrm{~h}}$ & $4.51 \pm 0.24^{\mathrm{a}}$ & $3.82 \pm 0.49^{\mathrm{b}}$ & $5.10 \pm 0.20^{\mathrm{c}}$ & $4.27 \pm 0.17^{\mathrm{a}, \mathrm{b}}$ \\
$\mathrm{SS}_{{ }_{\mathrm{hh}}\left({ }^{\circ} \text { Brix }\right)}$ & $10.00 \pm 0.00^{\mathrm{a}}$ & $6.00 \pm 0.00^{\mathrm{b}}$ & $10.00 \pm 0.00^{\mathrm{a}}$ & $6.00 \pm 0.00^{\mathrm{b}}$ \\
$\mathrm{SS}_{24 \mathrm{~h}}\left({ }^{\circ}\right.$ Brix $)$ & $5.10 \pm 0.31^{\mathrm{a}}$ & $3.05 \pm 0.16^{\mathrm{b}}$ & $10.00 \pm 0.16^{\mathrm{c}}$ & $3.00 \pm 0.00^{\mathrm{b}}$ \\
\hline
\end{tabular}

${ }^{*}$ Conditions marked with different letters present statistically significant difference with $95 \%$ of confidence $(p<0.05)$ by the Tukey test.

significant difference at $p=0.04$. In relation to flavor, the formulation $70 / 30 \mathrm{~g} \mathrm{~g}^{-1}$ (milk/açai) with the adapted kefir culture was better accepted (average score of 6.66) than the one from the original kefir culture (average score of 5.47). Similar result was obtained for the overall acceptance; the same formulation mentioned above presented an average score of 7.05 against the formulation $30 / 70 \mathrm{~g} \mathrm{~g}^{-1}(\mathrm{milk} / \mathrm{aça})$ with the original culture that scored 5.84 . 
Table 4. Sensorial analysis of the mixed fermented beverage of whole milk and açaí berry pulp using kefir. The acceptance test was made with 50 no trained panelists using a verbal hedonic scale of 9 points $\left(9=\right.$ like extremely to $1=$ dislike extremely). Formulations $\left(\mathrm{g} \mathrm{g}^{-1}\right)$ of whole milk/açaí berry evaluated were of 70/30 and 30/70; 2 different kefir cultures were employed - original from milk and original from water adapted to milk. Fermentations were carried out at room temperature $\left(\sim 25^{\circ} \mathrm{C}\right)$ without shaking for $24 \mathrm{~h}$.

\begin{tabular}{lcccc}
\hline & \multicolumn{2}{c}{ Original kefir culture } & \multicolumn{2}{c}{ Adapted kefir culture } \\
\hline Attributes & $70 / 30$ & $30 / 70$ & $70 / 30$ & $30 / 70$ \\
Color & $7.08 \pm 1.60^{\mathrm{a}}$ & $7.70 \pm 1.53^{\mathrm{a}}$ & $7.20 \pm 1.58^{\mathrm{a}}$ & $7.66 \pm 1.49^{\mathrm{a}}$ \\
Flavor & $5.47 \pm 1.93^{\mathrm{a}}$ & $5.94 \pm 1.88^{\mathrm{a}, \mathrm{b}}$ & $6.66 \pm 1.32^{\mathrm{b}}$ & $6.37 \pm 1.42^{\mathrm{a}, \mathrm{b}}$ \\
Taste & $5.81 \pm 2.6^{\mathrm{a}}$ & $5.68 \pm 2.16^{\mathrm{a}}$ & $6.61 \pm 1.63^{\mathrm{a}}$ & $6.47 \pm 1.35^{\mathrm{a}}$ \\
Sweetness & $6.31 \pm 1.97^{\mathrm{a}}$ & $5.92 \pm 2.14^{\mathrm{a}}$ & $7.02 \pm 1.62^{\mathrm{a}}$ & $6.45 \pm 1.42^{\mathrm{a}}$ \\
Acidity & $6.20 \pm 1.84^{\mathrm{a}}$ & $5.78 \pm 1.91^{\mathrm{a}}$ & $6.61 \pm 1.32^{\mathrm{a}}$ & $6.39 \pm 1.33^{\mathrm{a}}$ \\
Overall acceptance & $5.96 \pm 2.24^{\mathrm{a}, \mathrm{b}}$ & $5.84 \pm 2.06^{\mathrm{a}}$ & $7.05 \pm 1.37^{\mathrm{b}}$ & $6.50 \pm 1.40^{\mathrm{a}, \mathrm{b}}$ \\
\hline
\end{tabular}

*Conditions marked with different letters present statistically significant difference with $95 \%$ of confidence $(p<0.05)$ by the Tukey test.

\section{DISCUSSION}

The preliminary tests with the original kefir culture revealed a considerably high variability among the formulations analyzed, especially for the mass variation $(\Delta \mathrm{m}$, Figure $1 \mathrm{~A})$, this is probably explained due to the complex composition of the kefir culture, as well as by possible variations of temperature during the fermentation process, since it occurred at room temperature $\left(-25^{\circ} \mathrm{C}\right)$, without any interventions. Since no statistically significant difference among the formulations for $\Delta \mathrm{m}$ and $\mathrm{R}$ were observed (Table 1 ), which implies in the necessity of control of the fermentation conditions in order to grant a higher reproducibility, by means of temperature control and the utilization of a more homogeneous kefir culture. The inverse relation between the concentration of açai berry pulp in the formulation and the final concentration of soluble solids (SS) and the final pH (Figures 1B,C) can be attributed to the fact that the pulp is naturally more acid and contains less SS than the milk. In addition, the SS and $\mathrm{pH}$ decreases in time can be also related to the production of organic acids and substrate consumption that occurs during the growth and metabolism of the kefir culture.

The preliminary tests with the adapted kefir culture resulted in more reproducible results probably due to a greater homogeneity of the adapted culture, since the same temperature conditions, as the original culture, were applied. Furthermore, when analyzing formulation 1 (containing only milk) it was observed (Table 2) a significant difference for $\mathrm{R}$ in comparison to the other formulations, with greater yield. Nevertheless, a greater yield is merely related to a smaller substrate consumption, which implies in a slower growth of the adapted kefir culture. Therefore, it is possible to state that the adapted kefir culture is able to grow in milk; however, it develops better with the addition of the açai berry pulp to the formulation.

The fermentations, in ten replicates, showed (Table 3) that the original kefir culture had a greater cellular growth than the adapted one, probably due to the presence of milk which is its original substrate. The growth of the kefir culture observed in this study $(12 \%<\Delta \mathrm{m}<29 \%)$ is comparable to the values obtained by Weschenfelder et al. (2011) who observed increases from $0-20 \%$ in the mass of kefir biomass in pasteurized milk evaluated at $25^{\circ} \mathrm{C}$. When analyzing the $R$ values (Table 3 ) it is possible to observe that the smaller values were obtained with the original culture (confirming the better culture development) and for the adapted culture, higher concentrations of açai berry pulp could lead to a greater cellular growth and substrate consumption. Another important observation in relation to the adapted culture, that is, the obtainment of higher final $\mathrm{pH}$ values (Table 3) which could be a reflex of a lower growth rate, i.e., a smaller quantity of microorganisms resulted in a smaller production of acids as well as a smaller $\mathrm{pH}$ reduction.

In relation to the fermentations using the original and adapted kefir cultures, the $\mathrm{pH}$ values (Table 3) were similar to those reported by Santa et al. (2008), which obtained a final $\mathrm{pH}$ between 4.1 and 4.6 for kefir beverages, sweetened and mixed with fruit pulp. Weschenfelder et al. (2011) obtained lower values of $\mathrm{pH}$ (3.6 to 3.8) but these authors measured the $\mathrm{pH}$ only after the maturation stage ( $144 \mathrm{~h}$ ) which caused a reduction in $\mathrm{pH}$ values relative to the values obtained at the end of fermentation. In other study, Kök-Tas et al. (2013) obtained $\mathrm{pH}$ values between 4.29 and 4.53 for different fermentations using only kefir culture.

The SS values (also at Table 3) were similar compared to preliminary tests, however, it is noteworthy that in the

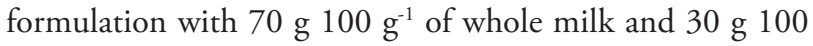
$\mathrm{g}^{-1}$ of açai berry pulp, the difference between the beginning and the end of the fermentation was zero, reinforcing the hypothesis that the minimum development of the adapted culture occurs when the substrate was formulated with more whole milk. In this case, the amount of substrate consumed should have been equal to the amount of acid liberated during the fermentation, causing no variation of soluble solid concentration. In the formulation using more quantity of açai 
berry pulp the behavior was identical for the two cultures, demonstrating that both developed well in conditions with less milk and more açaí berry pulp. Kök-Tas et al. (2013) obtained values of total solids ranging between 7.8 and 8.2 for different fermentations under normal and modified atmosphere.

For the sensory analysis, although there was no statistically significant difference for most of the evaluated attributes (Table 4), it is possible to observe that for 5 out of the 6 evaluated attributes, the formulation 70/30 $\mathrm{g} \mathrm{g}^{-1}$ (milk/aça $)$ using the adapted culture, had higher average scores than the others. Regarding the flavor, taste, sweetness and acidity, this fact is probably related to the higher $\mathrm{pH}$ obtained in this fermented beverage formulation. Regarding the color, the formulations prepared using more açai berry pulp resulted in a more intense color which is directly associated to the pulp and consequently it is more attractive to the consumer.

The sensory analysis conducted by Santa et al. (2008) presented average values of overall acceptance ranging from 6.0 to 7.5 for fermented beverage from kefir mixed with plum or strawberry pulp with different levels of sweetness. Puerari et al. (2012) obtained acceptance rates from 8.0 to 9.2 for the beverage of cocoa and kefir, fermented at $10^{\circ} \mathrm{C}$. Cui et al. (2013) achieved an acceptance level of 8.8 for the beverage of walnut and kefir, fermented for only $12 \mathrm{~h}$. Irigoyen et al. (2005) evaluated the effect of storage for 28 days over the sensorial acceptance of a kefir beverage and it was found that the best results were obtained after two days of storage. Based on all these references, the fermented beverages of whole milk and açai berry pulp using kefir obtained in this present study were not so different than the other beverages mentioned and show a good potential.

\section{CONCLUSION}

From the analysis of the effects of different compositions of milk and açaí berry pulp on the final fermented kefir beverage it was possible to select two formulations. It was observed that with a higher milk composition, the kefir grains (original from milk) development is favorable, but with a higher açaí berry pulp composition, and the adapted kefir culture, a better sensorial acceptance is obtained. In general, despite its natural acidity, the açai berry pulp is a good composition with milk for kefir fermentation and it is capable to differentiate a very common probiotic product.

\section{ACKNOWLEDGMENTS}

Authors would like to thank the Faculdade Municipal Franco Montoro (Mogi Guaçu -SP / Brazil), where all the experiments and analysis were conducted and also to the Coordenação de Aperfeiçoamento de Pessoal de Nível Superior (CAPES, Brazil) for the financial support.

\section{REFERENCES}

Balabanova, T.; Panayotov, P. 2011. Obtaining functional fermented beverages by using the kefir grains. Procedia Food Science, 1:1653-1659.

Bergmann, R.S.O.; Pereira, M.P.; Veiga, S.M.O.M.; Schneedorf, J.M.; Oliveira, N.M.S.; Fiorini, J.E. 2010. Microbial profile of a kefir sample preparations - grains in natura and lyophilized and fermented suspension. Ciência e Tecnologia de Alimentos, 30:1022-1026.

Cui, X.-H.; Chen, S.-J.; Wang, Y.; Han, J.-R. 2013. Fermentation conditions of walnut milk beverage inoculated with kefir grains. LWT - Food Science and Technology, 50:349-352.

Diniz, R.O.; Perazzo, F.F.; Carvalho, J.C.T.; Schneenedorf, J.M. 2003. Atividade Antiinflamatória de Quefir, um probiótico da medicina popular. Revista Brasileira de Farmacognosia, 13:19-21.

Dornelles, A.S.; Rodrigues, S. 2006. Fermentação alcoólica de caldo de cana utilizando grãos de kefir. Revista Ciência Agronômica, 37:386-390.

Hsieh, H.-H.; Wang, S.-Y.; Chen, T.-L.; Huang, Y.-L.; Chen, M.-Y. 2012. Effects of cow's and goat's milk as fermentation media on the microbial ecology of sugary kefir grains. International Journal of Food Microbiology, 157:73-81.

Irigoyen, A.; Arana, I.; Castiella, M.; Torre, P.; Ibáñez, F.C. 2005. Microbiological physicochemical, and sensory characteristics of kefir during storage. Food Chemistry, 90:613-620.

Kök-Tas,T.; Seydim, A.C.; Özer, B.; Guzel-Seydim, Z.B. 2013. Effects of different fermentation parameters on quality characteristics of kefir. Journal of Dairy Science, 96:780-789.

Leite, A.M.O.; Miguel, M.A.L.; Peixoto, R.S.R.; Soares, A.; Silva, J.T.; Paschoalin, V.M.F. 2013. Microbiological, technological and therapeutic properties of kefir: a natural probiotic beverage. Brazilian Journal of Microbiology, 44:341-349.

Lopitz-Otsoa, F.; Rementeria, A.; Elquezabal, N.; Garaizar, J. 2006. Kefir: A symbiotic yeast-bacteria community with alleged healthy capabilities. Revista Iberoamericana de Micologia, 23:67-74.

Miao, L.; Wu, T. 2014. Açaí (Euterpe oleracea Mart.) Liquefied Pulp for Drinking and their Antioxidant Capacities During Processing. In: Preedy, V.(Ed.). Processing and Impact on Antioxidants in Beverages. Academic Press, pp. 165-172.

Menezes, E.M.S.; Torres, A.T.; Srur, A.U.S. 2008. Valor nutricional da polpa de açaí (Euterpe oleracea Mart) liofilizada. Acta Amazonica, 38:311-316.

Moreira, M.E.C.; Pereira, I.O.; Santos, M.H.; Ferraz, V.; Barbosa, L.C.A.; Schneedorf, J.M. 2008. Atividade anti-inflamatória de carboidrato produzido por fermentação aquosa de grãos de quefir. Química Nova, 31:1738-1742.

Oliveira, P.A.A.C.; Silva, I.G.; Souza, M.L.; Furtado, C.M.; Silva,R.F. 2011. In natura açaí beverage: quality, pasteurization and acidification. Ciência e Tecnologia de Alimentos, 31:502-507.

Plessas, S.; Koliopoulos, D.; Kourkoutas, Y.; Psarianos, C.; Alexopoulos, A.; Marchant, R.; Banat, I.M.; Koutinas, A.A. 2008. Upgrading of discarded oranges through fermentation using kefir in food industry. Food Chemistry, 106:40-49. 
Puerari, C.; Magalhães, K.T.; Schaw, R.F. 2012. New cocoa pulpbased kefir beverages: Microbiological, chemical composition and sensory analysis. Food Research International, 48:634-640.

Santa, O.R.D.; Cardoso, F.; Mota, G.; Bastos, R.G.; Rigo, M.; Santa, H.S.D. 2008. Avaliação sensorial de kefir sabor ameixa e morango. Revista Brasileira de Agrociência, 14:77-85.

Stepaniak, L.; Fetliński, A. 2002. Fermented Milks - Kefir. In: J. Fuquay \& P. Fox P (Eds.), Encyclopedia of Dairy Sciences. Elsevier, pp. 1049-1054.

Stone, H.; Sidel, J.L. 1993. Sensory evaluation practices. 2nd ed. Academic Press, Redwood City, 338 p.

Soupioni, M.; Golfinopoulos, A.; Kanellaki, M.; Koutinas, A.A. 2013. Study of whey fermentation by kefir immobilized on low cost supports using 14C-labelled lactose. Bioresource Technology, 145:326-330.

Weschenfelder, S.; Pereira, G.M.; Carvalho, H.H.C.; Wiest, J.M. 2011. Caracterização físico-química e sensorial de kefir tradicional e derivados. Arquivos Brasileiros de Medicina Veterinária e Zootecnia, 63:473-480.

Recebido em 24/01/2016

Aceito em 26/04/2016 